\title{
Major Salivary Gland Cancer pTX TNM Finding v6 and $v 7$
}

National Cancer Institute

\section{Source}

National Cancer Institute. Major Salivary Gland Cancer pTX TNM Finding v6 and v7. NCI Thesaurus. Code C65079.

Major salivary gland cancer in which the primary tumor cannot be assessed. (from AJCC 6th and 7th Eds.) 